\title{
Nutritive Profile and Provitamin A Value of Sweet Potatoes Flours (Ipomoea batatas Lam) Consumed in Côte d'Ivoire
}

\author{
Gisèle A. Y. Koua ${ }^{1}$, Thierry L. Zoué ${ }^{1}$, Rose-Monde Mégnanou ${ }^{1}$ \& Sébastien L. Niamké \\ ${ }^{1}$ Laboratory of Biotechnology, UFR Biosciences, University of Félix Houphouët-Boigny, Côte d'Ivoire \\ Correspondence: Gisèle A. Y. Koua, Laboratory of Biotechnology, UFR Biosciences, University of Félix \\ Houphouët-Boigny, 22 BP 582 Abidjan 22, Côte d'Ivoire. E-mail: kouayahgisele@yahoo.fr
}

\author{
Received: April 7, $2018 \quad$ Accepted: April 21, $2018 \quad$ Online Published: June 23, 2018 \\ doi:10.5539/jfr.v7n5p36 URL: https://doi.org/10.5539/jfr.v7n5p36
}

\begin{abstract}
Sweet potato is an important food security crop in Sub-Saharan Africa. In Côte d'Ivoire, the roots are widely consumed as supplementary staple food or secondary food. The present study is conducted to highlight the nutritive composition, antinutrients and $\beta$-carotene contents of local sweet potatoes consumed in Côte d'Ivoire. The nutritive properties and antinutritive factors of these sweet potatoes were investigated using standard methods. Results confirmed the energetic value $(363 \pm 1.63-374.08 \pm 0.56 \mathrm{kcal} / 100 \mathrm{~g} \mathrm{DM})$ of whole sweet potato flour, mainly due to its high carbohydrate content $(86.75 \pm 0.40 \%-90.87 \pm 0.12 \%)$. Whole flour recorded low contents of moisture $(4.50 \pm 0.10-6.30 \pm 0.15 \%)$, lipids $(0.63 \pm 0.08-1.94 \pm 0.95 \%)$ and proteins $(0.94 \pm 0.36-1.91 \pm 0.15 \%)$. The antinutritive factors ranged from $55.84 \pm 0.13$ to $70.52 \pm 0.07 \mathrm{mg} / 100 \mathrm{~g}$ DM and $52.30 \pm 5.81-92.44 \pm 11.10 \mathrm{mg} / 100 \mathrm{~g}$ DM for oxalates and phytates, respectively. The mineral contents were: magnesium $(49.37 \pm 1.09-540.87 \pm 0.82 \mathrm{mg} / 100 \mathrm{~g} \mathrm{DM})$, calcium $(50.28 \pm 1.14-110.53 \pm 0.79 \mathrm{mg} / 100 \mathrm{~g} \mathrm{DM})$, phosphorus (25.12 $\pm 1.04-42.75 \pm 0.82 \mathrm{mg} / 100 \mathrm{~g} \mathrm{DM})$, potassium $(906.25 \pm 0.33-1625 \pm 0.61 \mathrm{mg} / 100 \mathrm{~g} \mathrm{DM})$, and iron $(5.62 \pm 0.84-26.89 \pm 0.76 \mathrm{mg} / 100 \mathrm{~g} \mathrm{DM})$. The sweet potato flours highlighted polyphenols and antioxidant activity varying from $92.80 \pm 98.20 \pm 1.72$ to $224.46 \pm 0.86 \mathrm{mg} \mathrm{GAE} / 100 \mathrm{~g} \mathrm{DM}$, and $31.03 \pm 0.52-58.63 \pm 0.60 \%$, respectively. While $\beta$-carotene levels of flours varied from $0.19 \pm 0.08$ to $22.71 \pm 0.67 \mu \mathrm{g} / \mathrm{g}$ DM for white to orange cultivars. At the whole, the orange fleshed sweet potato cultivars recorded an appreciable amount of minerals (magnesium, iron and calcium), polyphenols and greater antioxidant activity. This indicates that these sweet potato cultivars may present a potential asset for their using as natural antioxidants to prevent chronic diseases and undernourishment caused mineral deficiency. The results also showed that the orange-fleshed varieties may contribute for vitamin A deficiencies alleviation in children of rural areas of Côte d'Ivoire.
\end{abstract}

Keywords: sweet potato cultivar, sweet potato flour, nutritive profile, $\beta$-carotene, antioxidant activity

\section{Introduction}

Sweet potato (Ipomoea batatas Lam) is an important plant food grown throughout the tropics and subtropics countries (Fesco \& Boudion, 2002). It ranks seventh among the most important food crops worldwide with over 127 million metric tons annually produced (FAO, 2011; Ukom, Ojimelukwe, \& Alamu, 2011; Suraji, Ranaweera, Anil, \& Arthur, 2013). It has been considered as one of the most important food security crops which can grow under many ecological conditions, has a shorter growth period than most crops (Lou, Shimada, \& Rarkris, 2006; Hua et al., 2015). Sweet potato is commonly used as an inexpensive source of calories and dietary fiber (Vimala et al., 2011) and contains good amount of minerals (iron, calcium and potassium) and vitamins such as vitamin C and carotenoids, which confer nutritional advantage to the consumers (Bovell-Benjamin, 2007). Sweet potato varieties exist based on many colors of flesh, ranging from white, to orange colors with cream and yellow as intermediary colors. The intensity of the yellow or orange flesh color of sweet potato is correlated to the carotenoid content, mainly $\beta$-carotene $(2.9-150.6 \mu \mathrm{g} / \mathrm{g})$, that is known as precursor of vitamin A (Rodrigues-Amaya, 2011; Stathers, Benjamin, Katcher H., Balkenship \& Low, 2013). These varieties could therefore contribute to tackle vitamin A deficiency (VAD) when processed in best conditions (Bengtsson; Namutebi, Larsson, \& Svanberg, 2008; Bechoff et al. 2009). It is important to notify that vitamin A deficiency (VAD) is considered as a major public health problem in many areas of the world, mainly in sub-Saharan Africa (Nuss \& Tanumihardjo, 2010). Indeed, vitamin A deficiency is estimated to affect more than 250 million women and preschool children worldwide (WHO, 2010). African regions account for the greatest number of preschool 
children affected estimated to about 33 million (West, 2002). This deficiency is associated with the increased risk of morbidity and mortality, and ocular disorders such as night blindness and xerophthalmia, which affect infants, children and women during pregnancy and lactation (West, 2003). More recently, it has been reported that VAD is responsible for $20-24 \%$ of child mortality from diarrhea, measles and malaria and $3 \%$ mortality from infectious diseases (Rice, West, \& Black, 2004). The responses to address this deficiency include food fortification (Dary \& Mora, 2002), vitamin A supplementation (Beaton et al., 1993), diet diversification (Gibson $\&$ Hotz, 2001) and use of bio-fortified staple foods (Welch, 2002). In this manner, the use of bio-fortified staple foods (i.e. varieties bred for increased mineral and vitamin content) has been justified as a sustainable food-based approach to reach a large section of the rural population (Sayre et al., 2011). Recent studies investigated in many countries indicated that sweet potato has been selected for biofortification with provitamin A carotenoids by HarvestPlus Challenges Programme to contribute of reducing VAD in rural areas. Indeed, many studies show that orange-fleshed sweet potato (OFSP) can provide about twice the $\beta$-carotene needed for the recommended daily requirement of vitamin A (Low et al., 2007; Jenkins, Shanks \& Houghtaling, 2015). In Côte d'Ivoire, the consumption of sweet potato as staple food is not widespread. On the other hand, the prevalence of vitamin A deficiency is very high, estimated to 57\% among preschool aged children, $19 \%$ of pregnant women (WHO, 2009). More recently, most of sweet potato varieties including white, cream, pale yellow, yellow and orange flesh color, are commonly cultivated and available throughout the country. However, the nutritive composition of sweet potatoes cultivars cultivated in Côte d'Ivoire has not been investigated, because sweet roots are considered as secondary food (mainly yellow and orange fleshed cultivar). Additionally, sweet potato was generally cultivated for leaves consumption which constitute a highly appreciated leafy vegetable (Zoro, Zoué, Kra, Yépié, \& Niamké, 2013, Acho, Zoué, Akpa, Yapo, \& Niamké, 2014). Thus, the aim of the present study is to assess the nutritive composition of sweet potatoes varieties consumed in different areas of Côte d'Ivoire and evaluate their $\beta$-carotene contents in order to discuss their potentiality for reducing VAD among the Ivoirian children.

\section{Material and Methods}

\subsection{Sweet Potatoes Samples}

Six sweet potatoes cultivars including two white-fleshed, two yellow-fleshed and two orange-fleshed. They were purchased from five local markets of Côte d'Ivoire: Abidjan (geographic coordinates: $5^{\circ} 18^{\prime} 34^{\prime \prime} \mathrm{N} 4^{\circ} 00^{\prime} 45^{\prime \prime} \mathrm{W}$ ), Aboisso (geographic coordinates: $5^{\circ} 28^{\prime} 0^{\prime \prime} \mathrm{N} 3^{\circ} 12^{\prime} 0^{\prime \prime} \mathrm{W}$ ), Bouaké (geographic coordinates: $7^{\circ} 41^{\prime} 37^{\prime} \mathrm{N}$ $5^{\circ} 01^{\prime} 49^{\prime \prime} \mathrm{W}$ ), Guiglo (geographic coordinates: $6^{\circ} 32$ '37'N 7²9'3”W), and Korhogo (geographic coordinates: $9^{\circ} 27^{\prime} 28^{\prime \prime} \mathrm{N} 5^{\circ} 37^{\prime} 46^{\prime \prime} \mathrm{W}$ ). The flours were extracted from those cultivars using method described by Aryee et al. (2006) with slight modification (drying process was carried at $50^{\circ} \mathrm{C}$ during $48 \mathrm{~h}$ ), and were stored in desiccator until further analysis.

\subsection{Chemicals}

All solvents (n-hexane, acetone, ethanol and methanol) were purchased from Merck. Standards used (gallic acid, $\beta$-carotene) and reagents (metaphosphoric acid, Folin-Ciocalteu, DPPH, Butylated Hydroxytoluene (BHT)) were purchased from Sigma-Aldrich. All chemicals used in the study were of analytical grade.

\subsection{Proximate Analysis}

Moisture and ash contents were performed using official methods (AOAC, 1990), while pH values were determined using method described by AFNOR (1991). As for protein and lipid, their contents were evaluated with method of BIPEA (1976). Proteins were determined through the Kjeldhal method and the lipid content was determined by Soxhlet extraction using hexane as solvent. Reducing and total sugars content were quantified with method of Bernfeld (1955) and Dubois et al. (1956), respectively. For crude fiber content determination, method described by Wolf (1968) was performed. For this, two (2) g of sweet potato flour were weighed into separate $500 \mathrm{~mL}$ round bottom flasks and $100 \mathrm{~mL}$ of $0.25 \mathrm{M}$ sulphuric acid solution was added. The mixture obtained was boiled under reflux for $30 \mathrm{~min}$. Thereafter, $100 \mathrm{~mL}$ of $0.3 \mathrm{M}$ sodium hydroxide solution was added and the mixture were boiled again under reflux for $30 \mathrm{~min}$ and filtered through Whatman paper. The insoluble residue was then incinerated at $550^{\circ} \mathrm{C}$ in a muffle furnace for $3 \mathrm{~h}$ and ash obtained was weighed for the determination of crude fiber content.

Carbohydrates and starch contents were determined by difference. While energy value was calculated using factors (FAO, 1947):

$$
\text { Energy value }=2.74 \times \% \text { proteins }+4.03 \% \mathrm{x} \text { carbohydrates }+8.37 \% \mathrm{x} \text { lipids }
$$

Minerals including calcium, magnesium, sodium, potassium, iron, zinc and copper were determined using an 
Atomic Absorption Spectrophotometer, AAS (Model 372, Perkin-Elmer, Beaconsfield, UK) by wet digestion. While phosphorous level was determined using the phosphovanado molybdenate method (AOAC, 2012).

\subsection{Antioxidant Properties Evaluation}

\subsection{1 $\beta$-carotene Determination}

Extraction of carotenoids was performed by using a modification of the procedure described by Howe and Tanumihardjo (2006). Carotenoids were released from paste and flour sample of sweet potato cultivars ( $1 \mathrm{~g}$ of each sample) by heating at $85^{\circ} \mathrm{C}$ for $5 \mathrm{~min}$ in a mixture of ethanol with Butylated Hydroxytoluene (BHT, 0.1\%) followed by saponification with $400 \mu \mathrm{L} \mathrm{KOH} \mathrm{(80 \%} \mathrm{in} \mathrm{water).} \mathrm{The} \mathrm{resulting} \mathrm{suspension} \mathrm{was} \mathrm{mixed} \mathrm{by} \mathrm{vortex} \mathrm{for}$ $20 \mathrm{~s}$ and placed in a water bath at $85^{\circ} \mathrm{C}$ for $10 \mathrm{~min}$. The reaction was halted by placing in ice and mixing with 3 $\mathrm{mL}$ distillated water and $4 \mathrm{~mL}$ of hexane. The new suspension obtained was mixed by vortex for $20 \mathrm{~s}$ and centrifuged at $12000 \mathrm{rpm}$ for $10 \mathrm{~min}$. Following them, the supernatant was collected in flask and absorbance was measured at $450 \mathrm{~nm}$ by using a spectrophotometer (PG Instruments, England). $\beta$-carotene content was subsequently estimated according to the following formulas (Rodriguez-Amaya, 2001):

$$
\begin{aligned}
& X(\mu \mathrm{g})=\frac{\mathrm{A}^{*} \mathrm{y}(\mathrm{mL}) * 10^{6}}{\mathrm{~A}_{1 \mathrm{~cm}}{ }^{1 \%} 100} \\
& X(\mu \mathrm{g} / \mathrm{g})=\frac{\mathrm{X}(\mu \mathrm{g})}{\text { Weight of sample }(\mathrm{g})}
\end{aligned}
$$

Where $\mathrm{X}$ is the weight or concentration of $\beta$-carotene, $\mathrm{y}$ is the volume of the solution that gives an absorbance (A) at $450 \mathrm{~nm}$ and $\mathrm{A}^{1 \%}$ 1cm is the absorption coefficient of $\beta$-carotene in hexane estimated to 2592.

\subsubsection{Total Polyphenols and Flavonoid Determination}

Total polyphenols were extracted and determined using Folin-Ciocalteu's reagent (Singleton, Orthofer, \& Lamuela-Raventos, 1999). A quantity (1 g) of flour was soaked in $10 \mathrm{~mL}$ of methanol $70 \%$ and centrifuged at $1000 \mathrm{rpm}$ for $10 \mathrm{~min}$. An aliquot $(1 \mathrm{~mL})$ of supernatant was oxidized with $1 \mathrm{~mL}$ of Folin-Ciocalteu's reagent and neutralized by $1 \mathrm{~mL}$ of $20 \%$ sodium carbonate. The reaction mixture was incubated for $30 \mathrm{~min}$ at ambient temperature. Finally, the absorbance was measured at $745 \mathrm{~nm}$ by a spectrophotometer (PG Instruments, England) and used to calculate the polyphenols content using a standard curve based on gallic acid $(1 \mathrm{mg} / \mathrm{mL}$ with range of calibration curve: 0 - $0.8 \mathrm{mg}$ of gallic acid) as standard. Results were expressed as milligrams of gallic acid equivalent per $100 \mathrm{~g}$ DM.

Flavonoid content was determined by method of Meda et al. (2005). An aliquot $(0.5 \mathrm{~mL})$ of supernatant obtained previously was added $0.5 \mathrm{~mL}$ of distillated water, $0.5 \mathrm{~mL}$ of aluminum chloride $(10 \%), 0.5 \mathrm{~mL}$ of sodium acetate $(1 \mathrm{M})$ and $2 \mathrm{~mL}$ of distillated water. The reaction mixture was incubated for $30 \mathrm{~min}$ at ambient temperature and absorbance was measured at $415 \mathrm{~nm}$. Flavonoid content was estimated by using a calibration curve of quercetine $(0.1 \mathrm{mg} / \mathrm{mL}$ with the range of calibration: $0-0.05 \mathrm{mg}$ of quercetin) as standard.

\subsubsection{Antioxidant Activity}

Antioxidant activity assay was carried out using the 2.2-diphenyl-1-pycrilhydrazyl (DPPH) spectrophotometric method (Choi et al., 2002). About $1 \mathrm{~mL}$ of $0.3 \mathrm{mM}$ DPPH solution in ethanol was added to $2.5 \mathrm{~mL}$ of sample solution ( $1 \mathrm{~g}$ of flour mixed in $10 \mathrm{~mL}$ of methanol and filtered through Whatman $\mathrm{N}^{\circ} 4$ filter paper) and was allowed to react for $30 \mathrm{~min}$ at room temperature. Absorbance values were measured with a spectrophotometer (PG Instruments. England) set at $415 \mathrm{~nm}$. The average absorbance values were converted to percentage antioxidant activity using the following formula:

\section{Antioxidant activity $(\%)=100-[($ Abs of sample - Abs of blank $) \times 100 /$ Abs positive control $]$ \\ 2.5 Anti-nutritive Factors Determination}

Oxalates content was performed by using a titration method described by AOAC (1990). One (1) g of flour was weighed into $100 \mathrm{~mL}$ conical flask. A quantity of $75 \mathrm{~mL}$ of sulphuric acid $(3 \mathrm{M})$ was added and stirred for $1 \mathrm{~h}$ with a magnetic stirrer. The mixture was filtered and $25 \mathrm{~mL}$ of the filtrate was titrated while hot against KMnO4 solution $(0.05 \mathrm{M})$ to the end point.

Phytates contents were determined using the Wade's reagent colorimetric method (Latta \& Eskin, 1980). A quantity $(1 \mathrm{~g})$ of flour was mixed with $20 \mathrm{~mL}$ of hydrochloric acid $(0.65 \mathrm{~N})$ and stirred for $12 \mathrm{~h}$ with a magnetic 
stirrer. Then, the mixture was centrifuged at $12000 \mathrm{rpm}$ for $40 \mathrm{~min}$. An aliquot $(0.5 \mathrm{~mL})$ of supernatant was added with $3 \mathrm{~mL}$ of Wade's reagent. The reaction mixture was incubated for $15 \mathrm{~min}$ and absorbance was measured at $490 \mathrm{~nm}$ by using a spectrophotometer (PG Instruments, England). Phytates content was estimated using a calibration curve of sodium phytate $(10 \mathrm{mg} / \mathrm{mL})$ as standard.

\subsection{Statistical Analysis}

The triplicates values among treatments were analyzed using the analysis of variance (ANOVA) performed with XLSAT (Version 2015) to determine whether there were differences among the means. The Fisher's LSD test at $\mathrm{p}<0.05$, was also used to determine where the differences lied.

\section{Results and Discussion}

\subsection{Nutritive Value of the Sweet Potato Flours}

Proximate composition of the sweet potato flours is shown in Table 1. Moisture contents of the selected sweet potato flours was in the range of $4.50 \pm 0.10$ to $6.30 \pm 0.15 \%$. This range of moisture is reasonably comparable to the moisture content reported for others sweet potato flour of Nigeria and Ethiopia (Ohizua et al., 2016; Mitiku \& Teka, 2017). The low moisture value (lower than 10\%) obtained in this study agreed with the range of moisture generally accepted as standard value for dry products with a long self-life (Sriroth, Piyachomkwan, Wanlapatit, \& Oaste, 2000). This implies that, all the sweet potato flours investigated have good self-stability and could also resist to attack of spoilage microorganism. Based on the $\mathrm{pH}$ values recorded in the present study $(5.53 \pm 0.12$ to $5.95 \pm 0.89)$, the whole of the sweet potato flours could easily be used in pastry and bakery manufacturing because of their interesting $\mathrm{pH}$ which would indicate appreciable levels of starch safety (Apea-Bah et al., 2011). Concerning lipids and proteins, their contents $(\mathrm{p}<0.05)$ were low, and ranged from $0.63 \pm 0.08$ to $1.94 \pm 0.95 \%$ and $0.94 \pm 0.56 \%$ to $1.91 \pm 0.30 \%$, respectively. Yellow and orange-fleshed cultivars recorded relatively highest values (Table 1). However, the protein content recorded in this study confirmed the range (1-3\%) generally reported in the literature for most of roots and tubers, indicated they are not good choices to improve the protein content of food during the formula development (Dansby \& Bovell-Benjamin, 2003; Eleazu \& Ironua, 2013). Nevertheless, in order to supply the daily protein requirements, it would be necessary to supplement consumption of selected sweet potato flour with animal proteins or plant proteins, such as leafy vegetables and soybean, to have beneficial impact on protein-energy malnutrition.

As far as crude fiber content, values varied from $0.89 \pm 0.09$ to $2.92 \pm 0.16 \%$ for the white (WSPF-WC) and yellow fleshed cultivars (YSPF-WC), respectively. These values are similar to those reported in previous studies for other sweet potato roots cultivated in Benin and Ethiopia, respectively ( Sanoussi et al., 2016; Mitiku \&Teka, 2017). Nevertheless, the values are lower compared to those obtained by Kim et al. (2011) and Nicanuru et al. (2015), this indicate that these sweet potato cultivars are poor sources of dietary fiber. However, the appropriate consumption of selected sweet potato, especially the yellow and orange-fleshed varieties, may be advantageous. Indeed, according to the world health organization, dietary fiber help in digestion, prevention of colon cancer and protection against cardiovascular disease, colorectal cancer, diabetes and obesity (UICC/WHO, 2005).

Regarding the total sugars content $(6.10 \pm 0.45$ to $14.36 \pm 0.80 \%)$, the selected sweet potato flours may be considered as a good source of free sugars. The relatively high values of total sugars obtained in this study corroborate the finding of many researchers which showed that free or hydrolysable sugars are the most abundant sugar in raw sweet potato roots (Ingabire \& Hilda, 2011; Sanoussi et al., 2016). According to Salunke \& Kadam (1998), during storage of the tubers some starch were converted into free or hydrolysable sugars. This suggests that all the selected sweet potato flour could be recommended to act as natural sweeteners for food industries such as baby meal manufacturing in order to limit sugar addition from other sources. Moreover, due to low index glycemic indicated by Elong, Billard, \& Adenet. (2014), the selected sweet potato flours could be used for diabetic consumption in order to control glycaemia.

Ash contents of the studied sweet potato flours $(0.92 \pm 0.30-1.93 \pm 0.62 \%)$ corroborated the findings of many authors (van Hal, 2000; Eleazu \& Ironua, 2013). It is worth noting here that ash contents supplies a rough estimation on the minerals content of the product. Consequently, consumption of selected sweet potato flours should be advantageous to improve the nutritional value through their mineral composition.

For carbohydrates $(86.75 \pm 0.40-90.87 \pm 0.12 \%)$ and starch contents $(65.15 \pm 0.59-76.30 \pm 0.11 \%)$, the values obtained in this study were consistent with the findings previous reported by Fuglie \& Hermann (2004) and Suraji, Ranaweera, Gunaratne \& Bamunuarachchi (2013) which showed that sweet potato as other tubers and roots contain relatively great amounts of carbohydrates, mainly starch. The high carbohydrate content of sweet potatoes flours makes it a good source of energy, as revealed the energy values recorded in this study 
(363.44 $\pm 1.63-374.16 \pm 0.56 \%)$. Thus, the selected sweet potatoes flours could be used as an excellent raw material for household and many industries such as starch industry (Miller et al., 2003). They could contribute to create new economic and employment activities for farmers and cheap energy for rural people of Côte d'Ivoire.

Table 1. Proximate composition of sweet potatoes flours (for $100 \mathrm{~g}$ of edible portion/basis dry matter)

\begin{tabular}{lllllll}
\hline & OSPF-WC & OSPF-PC & YSPF-WC & YSPF-PC & WSPF-WC & WSPF-PC \\
\hline Moisture & $5.30 \pm 0.25^{\mathrm{c}}$ & $6.30 \pm 0.15^{\mathrm{a}}$ & $4.50 \pm 0.10^{\mathrm{d}}$ & $5.75 \pm 0.45^{\mathrm{b}}$ & $5.10 \pm 0.20^{\mathrm{c}}$ & $5.90 \pm 0.89^{\mathrm{ab}}$ \\
pH & $5.53 \pm 0.12^{\mathrm{d}}$ & $5.86 \pm 0.60^{\mathrm{bc}}$ & $5.95 \pm 0.89^{\mathrm{a}}$ & $5.90 \pm 0.35^{\mathrm{b}}$ & $5.83 \pm 0.65^{\mathrm{c}}$ & $5.53 \pm 0.76^{\mathrm{d}}$ \\
Reducing sugar & $0.55 \pm 0.15^{\mathrm{d}}$ & $0.36 \pm 0.06^{\mathrm{e}}$ & $0.62 \pm 0.18^{\mathrm{b}}$ & $0.81 \pm 0.20^{\mathrm{a}}$ & $0.28 \pm 0.10^{\mathrm{f}}$ & $0.56 \pm 0.05^{\mathrm{c}}$ \\
Total sugar & $12.50 \pm 0.35^{\mathrm{c}}$ & $8.54 \pm 1.20^{\mathrm{e}}$ & $13.95 \pm 0.65^{\mathrm{b}}$ & $14.36 \pm 0.80^{\mathrm{a}}$ & $6.10 \pm 0.45^{\mathrm{f}}$ & $11.92 \pm 0.25^{\mathrm{d}}$ \\
Lipid & $1.46 \pm 0.11^{\mathrm{c}}$ & $1.94 \pm 0.95^{\mathrm{a}}$ & $1.62 \pm 0.22^{\mathrm{b}}$ & $1.01 \pm 0.32^{\mathrm{d}}$ & $0.63 \pm 0.08^{\mathrm{f}}$ & $0.84 \pm 0.18^{\mathrm{e}}$ \\
Ash & $1.21 \pm 0.45^{\mathrm{d}}$ & $1.28 \pm 0.85^{\mathrm{cd}}$ & $1.46 \pm 0.28^{\mathrm{b}}$ & $1.93 \pm 0.62^{\mathrm{a}}$ & $0.92 \pm 0.30^{\mathrm{e}}$ & $1.36 \pm 0.08^{\mathrm{bc}}$ \\
Fiber & $2.80 \pm 0.30^{\mathrm{a}}$ & $1.29 \pm 0.14^{\mathrm{bc}}$ & $2.92 \pm 0.16^{\mathrm{a}}$ & $2.60 \pm 0.71^{\mathrm{a}}$ & $1.54 \pm 0.20^{\mathrm{b}}$ & $0.89 \pm 0.09^{\mathrm{c}}$ \\
Protein & $1.79 \pm 0.14^{\mathrm{a}}$ & $1.74 \pm 0.09^{\mathrm{a}}$ & $1.91 \pm 0.30^{\mathrm{a}}$ & $1.96 \pm 0.15^{\mathrm{a}}$ & $0.94 \pm 0.36^{\mathrm{c}}$ & $1.31 \pm 0.03^{\mathrm{b}}$ \\
Carbohydrate & $87.44 \pm 0.17^{\mathrm{c}}$ & $87.45 \pm 0.56^{\mathrm{c}}$ & $87.59 \pm 0.34^{\mathrm{c}}$ & $86.75 \pm 0.40^{\mathrm{d}}$ & $90.87 \pm 0.12^{\mathrm{a}}$ & $89.71 \pm 0.16^{\mathrm{b}}$ \\
Starch & $67.45 \pm 1.00^{\mathrm{d}}$ & $71.02 \pm 0.16^{\mathrm{b}}$ & $66.28 \pm 0.40^{\mathrm{e}}$ & $65.15 \pm 0.59^{\mathrm{f}}$ & $70.01 \pm 0.15^{\mathrm{c}}$ & $76.30 \pm 0.11^{\mathrm{a}}$ \\
Energy value & $369.52 \pm 0.31^{\mathrm{c}}$ & $373.42 \pm 0.45^{\mathrm{ab}}$ & $371.77 \pm 0.1 .91^{\mathrm{b}}$ & $363.44 \pm 1.63^{\mathrm{d}}$ & $374.08 \pm 0.56^{\mathrm{a}}$ & $372.16 \pm 0.31^{\mathrm{ab}}$ \\
\hline
\end{tabular}

Data are represented as means \pm SD $(n=3)$. Means in the lines with no common superscript differ significantly $(\mathrm{p}<0.05)$

OSPF-WC: orange sweet potato flour-white color; OSPF-PC: orange sweet potato flour-purple color; YSPF-WC: yellow sweet potato flour-white color; YSPF-PC: yellow sweet potato flour-purple color; WSPF-WC: white sweet potato flour-white color; WSPF-PC: white sweet potato flour-purple color.

Figure 1 shows the results of $\beta$-carotene estimation in the selected sweet potato tubers and flours. All the investigated sweet potato cultivars were significantly influenced $(\mathrm{p}<0.05)$ by both cultivar and the processing method. Indeed, it was observed that the levels of $\beta$-carotene varied with varieties and ranged from $0.38 \pm 0.05$ to $36.90 \pm 0.52 \mu \mathrm{g} / \mathrm{g} \mathrm{FW}$ and $0.19 \pm 0.08$ to $22.71 \pm 0.67 \mu \mathrm{g} / \mathrm{g}$ DM for raw and flours sweet potato, respectively. The amounts of $\beta$-carotene of the orange-fleshed varieties were greater than those of the yellow and white sweet potato ones. The result also revealed that the $\beta$-carotene values were correlated with intensity of sweet potato flesh color. Indeed, according to the reports of de Pee et al. (1995), provitamin A carotenoids such as $\beta$-carotene, are pigments that occur in yellow and orange colored fruits and vegetables. More recently, the findings reported by van Jaarsveld et al. (2005) in South Africa and by Jenkins et al. (2015) in Mozambique, revealed that consumption of orange-fleshed sweet potato could contribute to increase the vitamin A status of children. These authors concluded that orange-fleshed sweet potato could help tackling vitamin A deficiency in African countries. In these conditions, the orange-fleshed sweet potato could be recommended in infant food formulation. In view to the recommended dietary allowance for vitamin A for children aged to 1-3 years (300 $\mu \mathrm{g} \mathrm{RAE/day)} \mathrm{(Institute}$ of Medicine, 2001), consumption of $100 \mathrm{~g}$ of orange sweet potato flours would provide about $40 \%$ and $60 \%$ of the RDA for OSPF-WC and OSPF-PC cultivars, respectively. They could substantially contribute to control vitamin A deficiency in Côte d'Ivoire where over half (57\%) of preschool aged children, and $19 \%$ of pregnant women are faced to vitamin A deficiency (WHO, 2009).

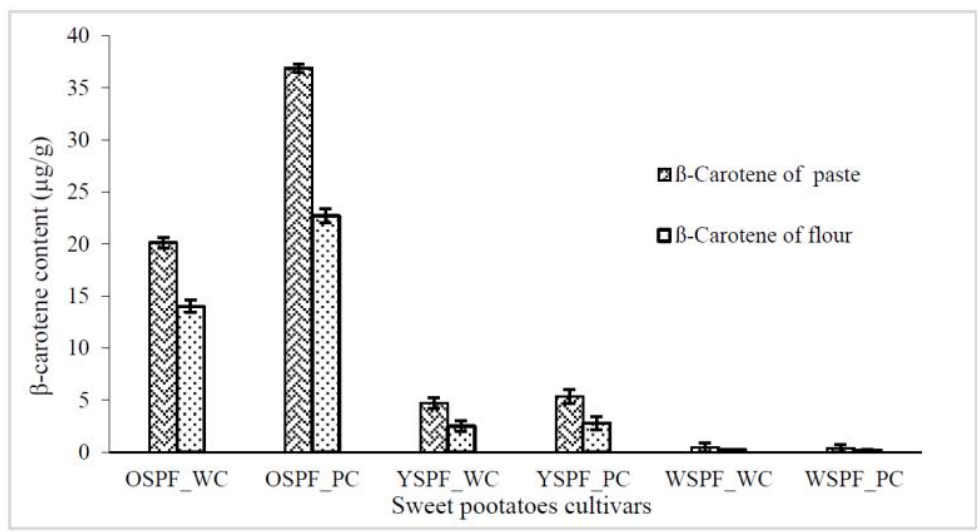

Figure 1. $\beta$-carotene content of sweet potatoes raw and flours

OSPF-WC: orange sweet potato flour-white color; OSPF-PC: orange sweet potato flour-purple color; YSPF-WC: yellow sweet potato flour-white color; YSPF-PC: yellow sweet potato flour-purple color; WSPF-WC: white sweet potato flour-white color; WSPF-PC: white sweet potato flour-purple color. 
The results of antioxidant properties (polyphenols, flavonoids contents and antioxidant activity) of the selected sweet potato flours are shown in Figures 2 and 3. Total polyphenols contents were in the range of $98.20 \pm 1.72$ to $224.46 \pm 0.86 \mathrm{mg} \mathrm{GAE} / 100 \mathrm{~g} \mathrm{DM}(\mathrm{p}<00.5)$ (Figure 2A). Among them, the orange cultivar (OSPF-PC) recorded the highest amount $(224.46 \pm 0.86 \mathrm{mg}$ GAE$/ 100 \mathrm{~g} \mathrm{DM})$, while the white cultivar (WSPF-PC) presented the lowest level $(98.20 \pm 1.72 \mathrm{mg} \mathrm{GAE} / 100 \mathrm{~g} \mathrm{DM})$. The total polyphenol concentration in our study was higher than values ( $94.63 \pm 1.40$ to $133.92 \pm 4.89 \mathrm{mg} \mathrm{GAE} / 100 \mathrm{FW}$ and 57 to $79 \mathrm{mg} / 100 \mathrm{~g} \mathrm{FW}$ ) previously reported by Truong et al. (2007) and Alam, Rana, \& Islam (2016), respectively. It important to notice that polyphenols groups are known to be the main dietary antioxidants derived from secondary metabolism of plants and confer higher in vitro antioxidant capacity than others compounds such as vitamins and carotenoids (Gardner, White, McPhail, \& Duthie, 2000). This group of compounds include phenolic acids, flavonoids, coumarins, stilbens, hydrolysable and condensed tannins (Naczk \& Shahidi, 2004). Considering the flavonoids content (Figure 2B), the results revealed that the orange cultivars $(8.67 \pm 0.34-11.16 \pm 0.18 \mathrm{mg} / 100 \mathrm{~g} \mathrm{DM})$ recorded the higher value, followed yellow cultivars $(4.71 \pm 0.15-6.67 \pm 0.12 \mathrm{mg} / 100 \mathrm{~g}$ DM) and white cultivars of sweet potato flour $(1.82 \pm 0.15-2.45 \pm 0.21 \mathrm{mg} / 100 \mathrm{~g} \mathrm{DM})$. Our results show that the levels of bioactive compounds (polyphenols and flavonoid) correlated with the difference of flesh color of sweet potato cultivars investigated. This confirm the findings of Rytel et al. (2014) which indicate that the content of phenolic compounds is usually correlated with the color of the sweet potato flesh. In other hand, it has been intensively investigated that polyphenolic compounds possess antioxidant properties which are benefits in human health. Thus, evaluation of DPPH radical scavenging activity of selected sweet potato flour (Figure 3) confirm the antioxidant capacity of the phenolics compounds presents in them. The results indicated that cultivar OSPF-PC (58.63\%) recorded high percentage, followed by OSPF-WC (54.10\%), YSPF-WC (45.30\%) and white cultivars which presented low level (31.03-31.30\%). This observation shows that there is a positive correlation between radical scavenging activity and total phenolics content of sweet potato flours studied. Our results are in agreement with the generally observed trend that high phenolic content results in high antioxidant activity (Dlamini, Taylor, \& Rooney, 2007; Siatka \& Kašparová, 2010). Based on this observation, consumption of orange sweet potato flours (OSPF-WC and OSPF-PC) should be encouraged since they contain relatively high amount of bioactive compounds which present antioxidant potential. They could help in the prevention of diseases that are associated with free radical damage and to reduce the risk of several chronic diseases, cardiovascular diseases, age-related diseases and cancer (D. Amić, D. Amić, Beslo, \& Trinajstić, 2003; Mervat \& Hanan, 2009).

Table 2 shows the mineral composition of selected sweet potato flours. There was a significant difference $(\mathrm{p}<0.05)$ between most of the analyzed minerals. Results revealed potassium $(906.25 \pm 0.33-2343.75 \pm 0.82$ $\mathrm{mg} / 100 \mathrm{~g} \mathrm{DM})$, magnesium $(49.37 \pm 1.09-540.87 \pm 0.82 \mathrm{mg} / 100 \mathrm{~g} \mathrm{DM})$ calcium $(50.28 \pm 1.14-110.53 \pm 0.79 \mathrm{mg} / 100$ g DM), phosphorus $(25.12 \pm 1.04-42.57 \pm 0.82 \mathrm{mg} / 100 \mathrm{~g} \mathrm{DM})$ and iron $(5.62 \pm 0.84-26.89 \pm 0.76 \mathrm{mg} / 100 \mathrm{~g} \mathrm{DM})$ as the most predominant minerals. The ratios $\mathrm{Ca} / \mathrm{P}$ and $\mathrm{Na} / \mathrm{K}$ varied from 1.41 to 4.18 and 0.006 to 0.016 , respectively. Based on the recommended dietary allowance (RDA) for children (1-3 years), magnesium (80 $\mathrm{mg}$ /day), calcium (700 mg/day), potassium (1400 mg/day) and iron ( $7 \mathrm{mg} /$ day $)$, the sweet potato flours studied could cover more than the half of RDA. For recall, calcium and phosphorus play an important role in human diet. Both are associated in the growth and maintenance of bones, teeth and muscles (Turan, Kordali, Zengin, Dursun, $\&$ Sezen, 2003). The values of the molar ratios $\mathrm{Ca} / \mathrm{P}$ ranged from 1.41 to 4.18 . About this ratio, Adeyeye \& Aye (2005) indicated that it is a good predictor of calcium availability. Indeed, $\mathrm{Ca} / \mathrm{P}$ values which are greater than 1 , suggests a good absorption of calcium, while values less than 0.5 indicates a poor calcium uptake.
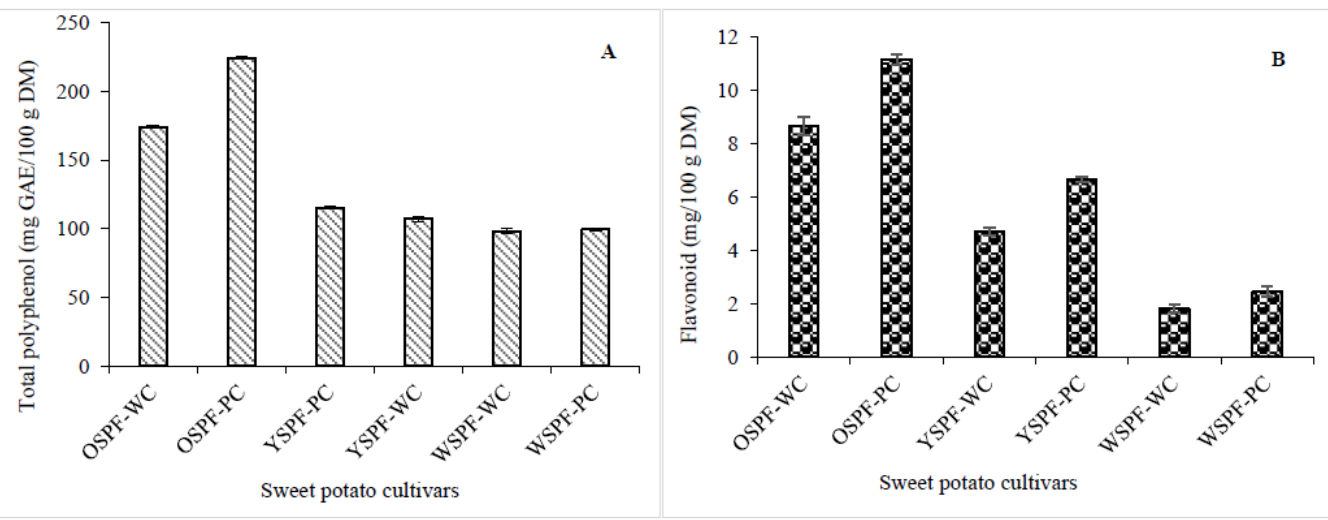

Figure 2. Total Polyphenol (A) and flavonoids (B) contents of sweet potatoes flours 


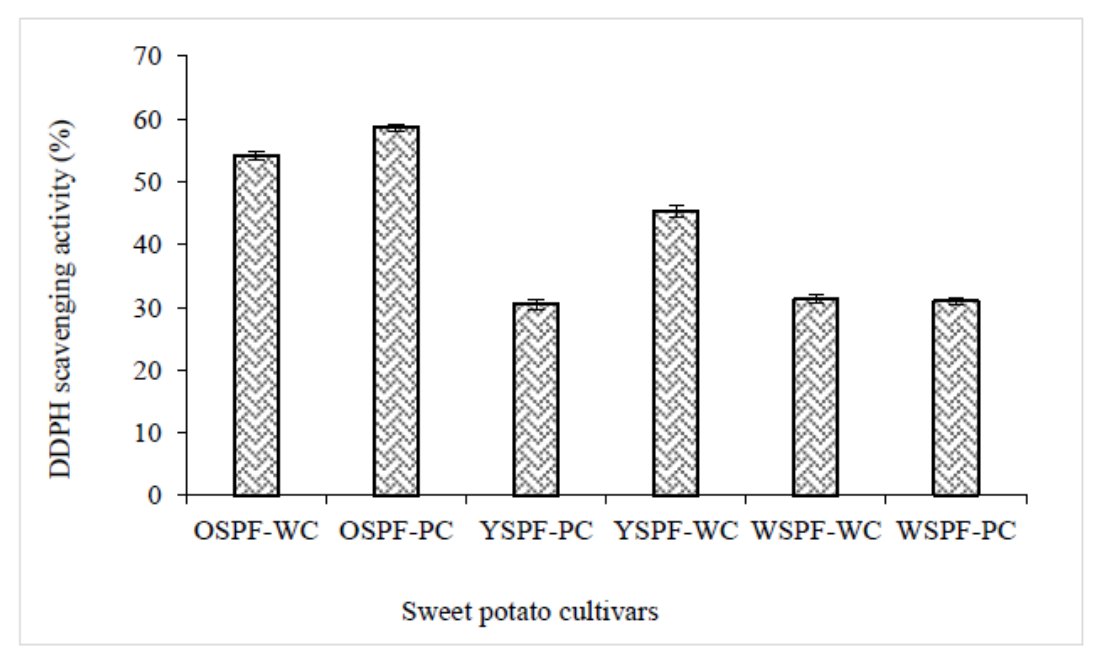

Figure 3. DDPH scavenging activity of sweet potatoes flours

OSPF-WC: orange sweet potato flour-white color; OSPF-PC: orange sweet potato flour-purple color; YSPF-WC: yellow sweet potato flour-white color; YSPF-PC: yellow sweet potato flour-purple color; WSPF-WC: white sweet potato flour-white color; WSPF-PC: white sweet potato flour-purple color.

In the present study, the ratios $\mathrm{Ca} / \mathrm{P}$ were higher than 1 , this may constitute a great advantageous and indicated a good intestinal absorption of calcium. As suggested in the Recommended Dietary Allowances (FND, 2005), consumption of the studied sweet potato flours could help to reduce high blood pressure diseases because $\mathrm{Na} / \mathrm{K}$ ratios were less than 1 (Table 2). As far as the content of magnesium is concerned, values are higher than those (18-30.40 mg/100 g DM) reported by Ukom, Ojimelukwe, \& Okpara (2009). It is important to notice that magnesium is an essential mineral element which is involved in interaction with calcium metabolism in bone and circulatory diseases as ischemic heart disease (Ishida et al., 2000). The present study also revealed that except for the cultivar YSPF-PC, the iron contents of the selected sweet potato were higher than the recommended dietary allowance for children (7 mg/day) (FND, 2005). Thus, consumption of selected sweet potato flours could be recommended in diets to improve iron status and help to prevent anemia. It is worth noting that anemia constitute a major problem of human health that affects more than $40 \%$ of preschool children in Africa. It caused many health consequences including poor pregnancy outcomes, impaired physical and cognitive development, reducing of work productivity and morbidity (Rohner et al., 2010; Staubli et al., 2001).

Table 2. Mineral composition of sweet potato flours (mg/100 g DM)

\begin{tabular}{lllllll}
\hline & OSPF-WC & OSPF-PC & YSPF-WC & YSPF-PC & WSPF-WC & WSPF-PC \\
\hline Calcium & $75.14 \pm 0.62^{\mathrm{c}}$ & $110.53 \pm 0.79^{\mathrm{a}}$ & $50.28 \pm 1.14^{\mathrm{e}}$ & $75.63 \pm 0.86^{\mathrm{c}}$ & $60.37 \pm 0.63^{\mathrm{d}}$ & $80.28 \pm 1.18^{\mathrm{b}}$ \\
Magnesium & $63.62 \pm 0.78^{\mathrm{d}}$ & $540.87 \pm 0.82^{\mathrm{a}}$ & $65.25 \pm 1.58^{\mathrm{d}}$ & $49.37 \pm 1.09^{\mathrm{e}}$ & $87.12 \pm 0.77^{\mathrm{c}}$ & $428.75 \pm 1.28^{\mathrm{b}}$ \\
Phosphorus & $32.60 \pm 0.69^{\mathrm{b}}$ & $26.32 \pm 0.76^{\mathrm{d}}$ & $33.16 \pm 0.52^{\mathrm{b}}$ & $25.12 \pm 1.04^{\mathrm{d}}$ & $42.57 \pm 0.82^{\mathrm{a}}$ & $28.94 \pm 0.82^{\mathrm{c}}$ \\
Sodium & $16.95 \pm 0.82^{\mathrm{a}}$ & $14.50 \pm 1.22^{\mathrm{b}}$ & $13.75 \pm 0.90^{\mathrm{bc}}$ & $13.85 \pm 0.73^{\mathrm{bc}}$ & $18.62 \pm 1.00^{\mathrm{a}}$ & $11.98 \pm 0.82^{\mathrm{c}}$ \\
Potassium & $1375 \pm 0.69^{\mathrm{c}}$ & $906.25 \pm 0.33^{\mathrm{f}}$ & $1343.75 \pm 0.82^{\mathrm{d}}$ & $1218.75 \pm 0.82^{\mathrm{e}}$ & $1625 \pm 0.61^{\mathrm{b}}$ & $1718.75 \pm 0.61^{\mathrm{a}}$ \\
Iron & $15.00 \pm 0.86^{\mathrm{b}}$ & $8.75 \pm 0.61^{\mathrm{c}}$ & $13.75 \pm 0.90^{\mathrm{b}}$ & $5.62 \pm 0.84^{\mathrm{d}}$ & $26.89 \pm 0.76^{\mathrm{a}}$ & $8.75 \pm 0.90^{\mathrm{c}}$ \\
Zinc & $0.95 \pm 0.16^{\mathrm{abc}}$ & $0.75 \pm 0.08^{\mathrm{cd}}$ & $1.03 \pm 0.10^{\mathrm{ab}}$ & $0.85 \pm 0.08^{\mathrm{bcd}}$ & $1.13 \pm 0.12^{\mathrm{a}}$ & $0.69 \pm 0.13^{\mathrm{d}}$ \\
$\mathbf{C o p p e r}$ & $0.725 \pm 0.10^{\mathrm{ab}}$ & $0.74 \pm 0.11^{\mathrm{a}}$ & $0.525 \pm 0.18^{\mathrm{ab}}$ & $0.515 \pm 0.12^{\mathrm{ab}}$ & $0.45 \pm 0.16^{\mathrm{b}}$ & $0.625 \pm 0.08^{\mathrm{ab}}$ \\
$\mathbf{C a} / \mathbf{P}$ & $2.30 \pm 0.00$ & $4.18 \pm 0.00$ & $1.51 \pm 0.00$ & $2.99 \pm 0.00$ & $1.41 \pm 0.00$ & $2.76 \pm 0.00$ \\
$\mathbf{N a} / \mathbf{K}$ & $0.012 \pm 0.00$ & $0.016 \pm 0.00$ & $0.006 \pm 0.00$ & $0.011 \pm 0.00$ & $0.011 \pm 0.00$ & $0.007 \pm 0.00$ \\
\hline
\end{tabular}

Data are represented as means \pm SD $(n=3)$. Means in the lines with no common superscript differ significantly $(\mathrm{p}<0.05)$.

OSPF-WC: orange sweet potato flour-white color; OSPF-PC: orange sweet potato flour-purple color; YSPF-WC: yellow sweet potato flour-white color; YSPF-PC: yellow sweet potato flour-purple color; WSPF-WC: white sweet potato flour-white color; WSPF-PC: white sweet potato flour-purple color

\subsection{Antinutritive Value of Sweet Potato Flours}

About oxalates and phytates, they are well known as antinutrients of plant food, and are associated with a decrease in bioavailability of many nutritionals minerals. These organic substances can bind essential minerals to form insoluble or indigestible complexes in the lumen of intestinal tracts, thereby impairing their absorption (Davis \& Olpin, 1979). Hence, in order to predict the bioavailability of divalent minerals such calcium and iron 
in human diet estimation of the phytate - to mineral or oxalate - to - mineral molar ratio were evaluated.

This evaluation constitute a valuable tool in predicting the inhibitory effect of phytate or oxalate on the bioavailability of minerals, such as iron or calcium (Hurrell, 2004; Ma et al., 2005). In the present study, results showed that oxalates and phytates contents varied from $55.84 \pm 0.13$ to $70.52 \pm 0.07 \mathrm{mg} / 100 \mathrm{~g}$ DM and $52.30 \pm 5.81-92.44 \pm 11.10 \mathrm{mg} / 100 \mathrm{~g} \mathrm{DM}$ (Table 3), respectively. It is important to know that oxalic acid and its salts can have deleterious effects on human nutrition and health, particularly by decreasing calcium absorption and aiding the formation of kidney stones (Noonan \& Savage, 1999). However, the level of oxalate recorded in these sweet potato flours is not a concern for normal healthy person, as toxic level for humans was set as $2-5 \mathrm{~g}$ (Hassan \& Umar, 2004). In comparison with the findings of Dako, Retta, \& Desse (2016), the means values of phytate recorded in this study are in agreement with the levels of phytates $(49.35 \pm 0.03-111.43 \pm 0.04 \mathrm{mg} / 100 \mathrm{~g})$ reported by these authors in different Ethiopian sweet potato cultivars. However, the results obtained in this study reveal a low level of phytate than those $(569.30-2257.84 \mathrm{mg} / 100 \mathrm{~g}$ ) reported by Ohizua et al. (2016). In sum, our results show a relatively low level of antinutrients in sweet potato flours investigated which could be attribute to processing methods. In the other hand, the results of estimation of [Oxalates]/[Ca] molar ratios of all of the investigated sweet potato flours revealed that the values obtained were below the critical level of 2.5 regarded to have an effect on calcium bioavailability (Hassen, K. Umar, \& Z. Umar, 2007). Unlike the previous ratio, the $[$ Phytates]/[Ca] in all the studied sweet potato flours were above the critical level of 0.24 (Ma et al., 2005). This situation shows poor calcium bioavailability due to phytate. It's the same case with iron because [Phytates]/[Fe] ratios (2.62-9.94) above 0.4 which is the critical ratio. Our results also indicate that the sweet potato flours have substantial amounts of oxalates and phytates, which could have adverse effects on the bioavailability of essential dietary minerals, especially $\mathrm{Ca}$ and $\mathrm{Fe}$. Thus, in order to reduce the effects of antinutrients in the flours studied, which may have health-hazard potential, proper processing (boiling and frying) before their consumption is recommended.

Table 3. Antinutritive factors of sweet potato flours

\begin{tabular}{lllllll}
\hline & OSPF-WC & OSPF-PC & YSPF-WC & YSPF-PC & WSPF-WC & WSPF-PC \\
\hline Phytate & $64.71 \pm 0.07^{\mathrm{c}}$ & $62.92 \pm 0.09^{\mathrm{d}}$ & $55.84 \pm 0.13^{\mathrm{f}}$ & $68.46 \pm 0.07^{\mathrm{b}}$ & $70.52 \pm 0.07^{\mathrm{a}}$ & $60.28 \pm 0.13^{\mathrm{e}}$ \\
Oxalates & $63.25 \pm 5.75^{\mathrm{bc}}$ & $52.30 \pm 5.81^{\mathrm{c}}$ & $68.42 \pm 11.40^{\mathrm{b}}$ & $92.44 \pm 11.15^{\mathrm{a}}$ & $63.75 \pm 5.80^{\mathrm{bc}}$ & $63.65 \pm 8.79^{\mathrm{bc}}$ \\
Oxalates/Ca & $0.84 \pm 0.03$ & $0.48 \pm 0.07$ & $0.91 \pm 0.22$ & $1.85 \pm 0.05$ & $1.06 \pm 0.02$ & $0.8 \pm 0.07$ \\
Phytate/Ca & $0.87 \pm 0.01$ & $0.57 \pm 0.03$ & $0.74 \pm 0.05$ & $1.37 \pm 0.06$ & $1.18 \pm 0.07$ & $0.75 \pm 0.35$ \\
Phytate/Fe & $4.31 \pm 0.02$ & $7.19 \pm 0.00$ & $9.94 \pm 0.05$ & $4.98 \pm 0.09$ & $2.62 \pm 0.02$ & $6.89 \pm 0.08$ \\
\hline
\end{tabular}

Data are represented as means \pm SD $(n=3)$. Means in the lines with no common superscript differ significantly $(\mathrm{p}<0.05)$.

OSPF-WC: orange sweet potato flour-white color; OSPF-PC: orange sweet potato flour-purple color; YSPF-WC: yellow sweet potato flour-white color; YSPF-PC: yellow sweet potato flour-purple color; WSPF-WC: white sweet potato flour-white color; WSPF-PC: white sweet potato flour-purple color.

\section{Conclusion}

The results of the present study revealed that all the investigated sweet potatoes flours contain appreciable amount of total sugars, carbohydrates, starch and high energy value. This suggests that they could suitably be promoted through different sectors of the food chain in order to improve food security among rural people in Côte d'Ivoire. Furthermore, this study also underlined the higher levels of total polyphenol, minerals especially magnesium, iron and calcium in sweet potato flour, mainly in the orange-fleshed cultivars. This suggests that these flours may have the potential for use as natural antioxidants which can act as a barrier to free radical damage and many types of cancer and other chronic diseases. They can also make it useful in human diet to prevent undernourishment caused by mineral deficiency. This study also revealed that orange fleshed sweet potato cultivars are relatively rich in $\beta$-carotene which is a precursor of vitamin A, and can play an important role in the reducing of vitamin A deficiencies in the children of rural area. While the production of other sweet potato cultivars is encouraged, the study findings suggest the consumption of orange fleshed sweet potato cultivars could address nutrient deficiencies. Therefore, it is necessary to increase public awareness about the beneficial role of orange fleshed sweet potato consumption.

\section{Acknowledgements}

Authors are grateful to ASCAD (Academy of Sciences, Culture, Arts and African Diaspora, Abidjan) by their contribution for financial support to this work.

\section{References}

Acho, C. F., Zoué L. T., Akpa, E. E., Yapo, V. G., \& Niamké, S. L. (2014). Leafy vegetables consumed in 
Southern Côte d'Ivoire: a source of high value nutrients. Journal of Animal Plant Sciences, 20(3), 3159-3170.

Adeyeye, E. I., \& Aye, P. A. (2005). Chemical composition and the effect of salts on the food properties of Triticum durum whole meal flour. Pakistan Journal of Nutrition, 4(3), 187-196.

Alam, M. K., Rana, Z. H., \& Islam, S. N. (2016). Comparison of the proximate composition, total carotenoids and total polyphenol content of nine orange-fleshed sweet potato varieties grown in Bangladesh. Foods, 5(3), 64-74. https://doi.org/10.3390/foods5030064.

Alinnor, I. J., \& Oze, R. (2011). Chemical evaluation of the nutritive value of Pentaclethra macrophyllabenth (African Oil Bean) seeds. Pakistan Journal of Nutrition, 10(4), 355-359. https://doi.org/10.3923/pjn.2011.355.359.

Amić, D., Amić, D., Beslo, D. D., \& Trinajstić, N. (2003). Structure-radical scavenging activity relationship of flavonoids. Croatia Chemica Acta, 76(1), 56-61.

Apea-Bah, F. B., Oduro, I., Ellis, W. O., \& Safo-Kantanka, O. (2011). Factor analysis and age at harvest effect on the quality of flour from four cassava varieties. World Journal of Dairy and Food Sciences, 6(1), 43-54.

Aryee, F. N., Oduro, I., Ellis, W. O., \& Afuakwa, J. J. (2006). The physicochemical properties of flours samples from the roots of 31 varieties of cassava. Food Control, 17(11), 916-922. https://doi.org/10.1016/j.foodcont.2005.06.013.

Association Française de Normalisation. (1991). Recueil des normes françaises des céréales et des produits céréaliers. $3^{\mathrm{e} m e} \mathrm{Ed}$.

Association of Official Analytical Chemists. (1990). Official methods of analysis. Association of Official Analytical Chemists. $18^{\text {th }}$ ed. Washington, DC.

Association of Official Analytical Chemists. (2012). Official Methods of Analysis of the Association of Official Analytical Chemists. $19^{\text {th }}$ ed. Washington, DC.

Beaton, G. H., Martorell, R., Aronson, K. J., Edmonston, B., McCabe, G., Ross, A. C., \& Harvey, B. (1993). Effectiveness of vitamin A supplementation in the control of young child morbidity and mortality in developing countries. United Nations ACC/SCN state of the art series: Nutrition policy discussion, Paper no. 13. Geneva: Administrative Committee on Coordination/Subcommittee on Nutrition.

Bechoff, A., Dufour, D., Dhuique-Mayer, C., Marouze, C., Reynes, M., \& Westby, A. (2009). Effect of hot air, solar and sun drying treatments on provitamin A retention of orange-fleshed sweet potato. Journal of Food Engineering, 92(2), 164-171. https://doi.org/10.1016/j.jfoodeng.2008.10.034

Bengtsson, A., Namutebi, A., Larsson, A. M., \& Svanberg, U. (2008). Effects of various traditional processing methods on the all-trans- $\beta$-carotene content of orange-fleshed sweet potato. Journal of Food Composition and Analysis, 21(2), 134-143. https://doi.org/10.1016/j.jfca.2007.09.006

Bernfeld, D. (1955). Amylase $\beta$ et $\alpha$. In: S. P Colowick, \& Kaplan N.O. (Academic Press). Method in enzymology (vol. 1, pp. 149-154). New York.

Bhandari, M. R., \& Kawabata, J. (2004). Assessment of antinutritional factors and bioavailability of calcium and zinc in wild yam (Dioscorea spp.) tubers of Nepal. Food Chemistry, 85(2), 281-287. https://doi.org/10.1016/j.foodchem.2003.07.006

Bouis, H. E., Graham, R. D., \& Welch, R. M. (2000). The Consultative Group on International Agricultural Research (CGIAR) Micronutrients project: Justification and objectives. Food Nutrition Bulletin, 21(4), 374-381. https://doi.org/10.1177/156482650002100406

Bouis, H. E., Hotz C., McClafferty, B., Meenakshi, J. V., \& Pfeiffer, W. (2011). Biofortification: A new tool to reduce micronutrient malnutrition. Food Nutrition Bulletin, 32(1 Suppl), S31-S40. https://doi.org/10.1177/15648265110321S105

Bouwkamp, J. C. (1985). Sweet potato products: A material resource for the tropics. Introduction-Part I: CRC Press. Inc. Bae Raton.

Bovell-Benjamin, A. C. (2007). Sweet Potato: A review of its past, present, and future role in human nutrition. Advances in Food Nutrition and Research, 52, 1-59. https://doi.org/10.1016/S1043-4526(06)52001-7

Bureau International d'Etudes Analytiques. (1976). Recueil de méthodes d'analyses des communautés européennes. Gennevillier. 
Choi, C. W., Kim, S. C., Hwang, S. S., Choi, B. K., Ahn, H. J., Lee, M. Z., .. Kim, S. K. (2002). Antioxidant activity and free radical scavenging capacity between Korean medicinal plant and flavonoids by assay guided comparison. Plant Science, 163(6), 1161-1168. https://doi.org/10.1016/S0168-9452(02)00332-1

Dako, E., Retta, N., \& Desse, G. (2016). Comparison of three sweet potato (Ipomoea batatas (L.) Lam) varieties on nutritional and anti-nutritional factors. Global Journal of Science Frontier Research, 16(4), 63-72.

Dary, O., \& Mora, J. O. (2002). Food fortification to reduce vitamin A deficiency: International vitamin A consultative group recommendations. Journal of Nutrition, 132(9suppl), 2927S-2933S. https://doi.org/10.1093/jn/132.9.2927S

Davis, N. T., \& Olpin, S. (1979). Studies on the phytate: Zinc molar content in diet as a determinant of zinc availability to young rats. British Journal of Nutrition, 4l(3), 590-603. https://doi.org/10.1079/BJN19790074

de Pee, S, West, C. E., Muhilal, K. D., \& Hautvast, J. G. (1995). Lack of improvement in vitamin A status with increased consumption of dark-green leafy vegetables. Lancet, 46(8967), 75-81. https://doi.org/10.1016/S0140-6736(95)92111-7.

de Pee, S., West, C. E., Muhilal, K. D., \& Hautvast, J. G. A. J. (1995). Lack of improvement in vitamin A status with increased consumption of dark green leafy vegetables. Lancet, 346(8967), 75-81. https://doi.org/10.1093/ajcn/68.5.1058

De Ruiter, D. (1978). Composite flours. Pomeranz Y. (Ed). Advances in Cereal Science and Technology. (Vol II. pp. 349-385). St. Paul: AACC.

Dlamini, N. R., Taylor J. R. N., \& Rooney, W. L. (2007). The effect of sorghum type and processing on the antioxidant activity of African sorghum-based foods. Food Chemistry, 105(4), 1412-1419. https://doi.org/10.1016/j.foodchem.2007.05.017

Dubois, M., Gilles, K., Hamilton, J., Rebers, P., \& Smiths, F. (1956). Colorimetric method for determinations of sugars and related substances. Analytical Chemistry, 28(3), 350-356. https://doi.org/10.1021/ac60111a017

Eleazu C. O., \& Ironua, C. (2013). Physicochemical composition and antioxidant properties of a sweet potato variety (Ipomoea batatas L) commercially sold in South Eastern Nigeria. African Journal of Biotechnology, 12(7), 720-727. https://doi.org/10.5897/AJB12.2935

Ellong, E. N., Billard, C., \& Adenet, S. (2014) Comparison of physicochemical, organoleptic and nutritional abilities of eight sweet potato (Ipomoea batatas) varieties. Food and Nutrition Sciences, 5(2), 196-211.

Fesco, O. L., \& Boudion, O. W. (2002). Food and nutrition security for human security. Proceedings of International Conference on Vegetables (pp. 11-13). Rome, Italy.

Food and Agriculture Organization. (1947). Compositions des aliments en principes nutritifs calorifiques. FAO, Washington. D.C., USA.

Food and Agriculture Organization. (2011). Statistical database. Retrieved from http://faostat.fao.org/site/567/DesktopDefault.aspx?PageID=567\#ancor.

Food Nutrition Board (FND). (2005). Dietary reference intake for energy, carbohydrate, fiber, fat, fatty acids, cholesterol, protein and amino acid (micro-nutrients). Retrieved from The National Academic Press https://doi.org/10.17226/10490.

Fuglie, K. O., \& Hermann, M. (Eds). (2004). Sweet potato post-harvest research and development in China. Proceedings of an International Workshop held in Chengdu. International Potato Center (CIP). Bogor, Indonesia.

Gardner, P.T., White, T. A. C., McPhail, D. B., \& Duthie, G. G. (2000). The relative contributions of vitamin C, carotenoid and phenolics to the antioxidant potential of fruit juices. Food Chemistry, 68(4), 471-474. https://doi.org/10.1016/S0308-8146(99)00225-3

Gibson, R. S., \& Hotz, C. (2001). Dietary diversification/modification strategies to enhance micronutrient content and bioavailability of diets in developing countries. British Journal of Nutrition, 85(Suppl 2), S159-S166. https://doi.org/10.1079/BJN2001309

Hagenimana, V., \& Low, J. (2000). Potential of orange-fleshed sweet potatoes for raising vitamin A intake in Africa. Food Nutrition Bulletin, 21(4), 414-418. https://doi.org/10.1177/156482650002100414

Hassan, L. G., \& Umar, K. J. (2004). Antinutritive factors in African locust bean (Parkia biglobosa). Proceesings 
of the $27^{\text {th }}$ International Conference of the Chemical Society of Nigeria (pp. 322-326).

Hassan, L.G., Umar, K.J., \& Umar, Z. (2007). Antinutritive factors in Tribulus terrestris (Linn) leaves and predicted calcium and zinc bioavailability. Journal of Tropical Biosciences, 7, 33-36.

Howe, J. A., \& Tanumihardjo, S. A. (2006). Evaluation of analytical methods for carotenoid extraction from biofortified maize (Zea mays sp.). Journal of Agriculture Food Chemistry, 54(21), 7992-7797. https://doi.org/10.1021/jf062256f

Hua, J., Haixin, Z., Hongtao, L., \& Yunchao, L. (2015). Analysis on the nutritional composition and antioxidant activity of different types of sweet potato cultivars. Journal of Food and Nutrition Science, 6(1), 161-167. https://doi.org/10.4236/fns.2015.61017

Institute of Medicine. (2001). Dietary Reference Intakes for Vitamin A, Vitamin K, Arsenic, Boron, Chromium, Copper, Iodine, Iron, Manganese, Molybdenum, Nickel, Silicon, Vanadium, and Zinc. National Academy Press (pp. 65-126). Washington, DC.

Ishida, H., Suzuno, H., Sugiyama, N., Innami, S., Tadokoro, T., \& Maekawa, A. (2000). Nutritive evaluation on chemical components of leaves, stalks and stems of sweet potatoes (Ipomoea batatas poir). Food Chemistry, 68(3), 359-367. https://doi.org/10.1016/S0308-8146(99)00206-X

Jenkins, M., Shanks C. B., \& Houghtaling, B. (2015). Orange-fleshed sweet potato: Successes and remaining challenges of the introduction of a nutritionally superior staple crop in Mozambique. Food Nutrition Bulletin, 36(3), 327-353. https://doi.org/10.1177/0379572115597397

Kim, J. M., Park, S. J., Lee, C. S., Ren, C., Kim, S. S., \& Shin, M. (2011). Functional properties of different Korean sweet potato varieties. Food Sciences and Biotechnology, 20(6), 1501-1507. https://doi.org/10.1007/s10068-011-0208-1

Latta, M., \& Eskin M. (1980). A simple method for phytate determination. Journal of Agricultural Food Chemestry, 28(6), 1313-1315. https://doi.org/10.1021/jf60232a049

Lou, R., Shimada, T., \& Rarkris, T. (2006). Efficient embryogenic callus formation in sweet potato (Ipomoea batatas L. Lam.). Breeding Science, 46, 257-260.

Low, J. W., Arimond, M., Osman, N., Cunguara, B., Zano, F., \& Tschirley, D. (2007). A food-based approach introducing orange-fleshed sweet potatoes increased vitamin A intake and serum retinol concentrations in young children in rural Mozambique. Journal of Nutrition, 137(5), 1320-1327. https://doi.org/10.1093/jn/137.5.1320

Low, J., Walker, T., \& Hijmans, R. (2010). The Potential Impact of Orange-fleshed Sweet Potatoes on Vitamin A Intake in Sub-Saharan Africa. In: The VITAA Project, Vitamin A and Orange fleshed Sweet potatoes in Sub-Saharan Africa. Proceedings of the Workshop on the Food-based Approaches to Human Nutritional Deficiencies; 2001 May 9-11 (pp. 1-16). Nairobi, Kenya.

Ma, G., Jin, Y., Piao, J., Kok, F, Guusje, B., \& Jacobsen, E. (2005). Phytate, calcium, iron, and zinc and their molar ratios in foods commonly consumed in China. Journal of Agricultural Food Chemistry, 53(26), 10285-10290. https://doi.org/10.1021/jf052051r

Meda, A., Laien, C. E., Romito, M., Millogo, J., \& Nacoulma, O. G. (2005). Determination of total phenolic, flavonoid and proline contents in Burkina Faso honeys as well as well as their radical scavenging activity. Food Chemistry, 91(3), 571-577. https://doi.org/10.1016/j.foodchem.2004.10.006

Meenakshi, J. V., Johnson, N. L., Manyong, V. M., Degroote, H., Javelosa, J., Yanggen, ... Meng, E. (2010). How cost-effective is biofortification in combating micronutrient malnutrition? An Ex ante assessment. World Development, 38(1), 64-75. https://doi.org/10.1016/j.worlddev.2009.03.014

Mervat, M. M. El-F., \& Hanan, A. A. T. (2009). Antioxidant activities, total anthocyanins, phenolics and flavonoids contents of some sweet potato genotypes under stress of different concentrations of sucrose and sorbitol. Australian Journal of Basic and Applied Sciences, 3(4), 3609-3616.

Miller, S. A., Dean, D., Ganguli, S., Abdalla, M., \& Bovell-Benjamin, A. C. (2003). Physicochemical and viscometric properties of a sweet potato syrup. Association of Research Directors, Inc., $13^{\text {th }}$ Biennial Research Symposium. Atlanta, GA.

Mitiku, D. H., \& Teka, T. A. (2017). Nutrient and antinutrients composition of improved sweet potato [Ipomea batatas (L) Lam] varieties grown in eastern Ethiopia. Nutrition and Food Science, 47(3): 369 - 380. https://doi.org/10.1108/NFS-07-2016-0098 
Naczk, M., \& Shahidi, F. (2004). Extraction and analysis of phenolics in food. Journal of Chromatography A, 1054(1-2), 95-111. https://doi.org/10.1016/j.chroma.2004.08.059

Nicanuru, C., Laswai, H. S., \& Sila, D. N. (2015). Effect of sun- drying on nutrient content of orange fleshed sweet potato tubers in Tanzania. Sky Journal of Food Science, 4(7), 91-101.

Noonan, S. C., \& Savage, G. P. (1999). Oxalic acid and its effects on humans. Asia pacific Journal of Clinical Nutrition, 8(1), 64-74. https://doi.org/10.1046/j.1440-6047.1999.00038.x

Nuss, E. T., \& Tanumihardjo, S. A. (2010). Maize: a paramount staple crop in the context of global nutrition. Comprehensive Review in Food Science and Food Safety, 9(4), 417-436. https://doi.org/10.1111/j.1541-4337.2010.00117.x

Ohizua1, E. R., Adeola, A. A, Idowu, M. A., Sobukola1 O. P., Afolabi, T. A., Ishola, R. O., Ayansina S. O., Oyekale, T. O., Falomo, A. (2016). Nutrient composition, functional, and pasting properties of unripe cooking banana, pigeon pea, and sweet potato flour blends. Food Sciences and Nutrition, 5(3), 750-762. https://doi.org/ 10.1002/fsn3.455

Rice, A. I., West K. P., \& Black, R. E. (2004). Vitamin A deficiency: Comparative quantification of health risks. Retrieved from http://www.who.int/publications/cra/chapters/volume1/0211-0256.pdf.

Rodriguez-Amaya, D. B. (2001). A guide to carotenoid analysis in foods (Unpublished doctoral dissertation). Universida de Estadual de Campinas, Brasil.

Rohner, F., Zimmermann, M. B, Amon, R. J., Vounatsou, P., Tschannen, A. B., N'goran E. K., ... Hurrell, R. F. (2010). In a randomized controlled trial of iron fortification, anthelmintic treatment, and intermittent preventive treatment of malaria for anemia control in Ivorian children, only anthelmintic treatment shows modest benefit. Journal of Nutrition, 140(3), 635-641. https://doi.org/10.3945/jn.109.114256

Rytel, E., Tajner-Czopek, A., Kita, A., Aniołowska, M., Kucharska, A. Z., Sokół-Łetowska, A., \& Hamouz, K. (2014). Content of polyphenols in coloured and yellow fleshed potatoes during dices processing. Food Chemistry, 161, 224-229. https://doi: 10.1016/j.foodchem.2014.04.002

Sanoussi, A. F., Adjatin, A., Dansi, A., Adebowale, A., Sanni, L. O., \& Sanni, A. (2016). Mineral composition of ten elites sweet potato (ipomoea batatas [1.] lam.) landraces of Benin. International Journal of Current Microbiology and Applied Sciences, 5(1), 103-115. http://dx.doi.org/10.20546/ijcmas.2016.501.009

Sanoussi, A. F., Dansi, A., Bokossa-yaou, I., Dansi, M., Egounlety, M., Sanni, L. O., \& Sanni. A. (2013). Formulation and biochemical characterization of sweet potato (Ipomoea batatas) based infant flours fortified with soybeanand sorghum flours. International Journal of Current Microbiology and Applied Sciences, 2(7), 22-34. https://doi.org/10.13140/2.1.2664.5121

Sayre R., Beeching, J. R., Cahoon, E. B., Egesi C., Fauquet, C., Fellman, J., ... Zhang, P. (2011). The BioCassava plus program: biofortification of cassava for sub-Saharan Africa. Annual Review of Plant Biology, 62, 251-272. https://doi.org/10.1146/annurev-arplant-042110-103751

Siatka, T., \& Kašparová, M. (2010). Seasonal variation in total phenolic and flavonoid contents and DPPH scavenging activity of Bellis perennis L. flowers. Molecules, 15(12), 9450-9461. https://doi.org/10.3390/molecules 15129450

Singleton, V. L., Orthofer, R., \& Lamuela-Raventos, R. M. (1999). Analysis of total phenols and other oxydant substrates and antioxydants by means of Folin-Ciocalteu reagent. Methods in Enzymology, 299, 152-178. https://doi.org/10.1016/S0076-6879(99)99017-1

Sriroth, K. Piyachomkwan, K., Wanlapatit, S., \& Oaste, G. G. (2000). Cassava starch technology: The Thailand experience. Starch/Sarke, 52(12), 439-449. https://doi.org/10.1002/1521-379X(200012)52:12<439::AID-STAR439>3.0.CO;2-E

Stathers, T., Benjamin, M., Katcher, H., Balkenship, J., \& Low, J. (2013). Everything you ever wanted to know about sweet potato: Reaching Agents of Change. https://doi.org/10.4160/9789290604273.v2

Staubli, A. F., Adou, P., Davidsson, L., Cook, J. D., \& Hurrell, R. F. (2001). Prevalence of iron deficiency with and without concurrent anemia in population groups with high prevalence of malaria and other infections: A study in Côte d'Ivoire. American Journal of Clinical Nutrition, 74(6), 776-782. https://doi.org/10.1093/ajen/74.6.776

Suraji, A. S., Ranaweera, K. K. D. S., Anil, G., \& Arthur, B. (2013). Comparative analysis of nutritional quality of five different cultivars of sweet potatoes (Ipomea batatas (L) Lam) in Sri Lanka. Food Science and 
Nutrition, 1(4), 284-291. https://doi.org/10.1002/fsn3.38

Tibble, D. L. (1998). Further evidence of the cardiovascular benefits of diets enriched in carotenoids. American Journal of Clinical Nutrition, 68(3), 521-522. https://doi.org/10.1093/ajen/68.3.521

Truong, V. D., McFeeters, R. F., Thompson, R. T., Dean, L. L., \& Shofran, B. (2007). Phenolic acid content and composition in leaves and roots of common commercial sweet potato (Ipomea batatas L.) cultivars in the United States. Journal of Food Science, 72(6), C343-C349. https://doi.org/10.1111/j.1750-3841.2007.00415.x

Turan, M., Kordali, S., Zengin, H., Dursun, A., \& Sezen, Y. (2003). Macro and micro-mineral content of some wild edible leaves consumed in Eastern Anatolia. Soil and Plant Science, 53(3), 129-137. https://doi.org/10.1080/090647103100095

Ukom, A. N., Ojimelukwe P., \& Okpara, D. A. (2009). Nutrient composition of select sweet potato [Ipomoea batatas (L. lam)] varieties as influenced by different level of nitrogen fertilizer application. Pakistan Journal of Nutrition, 8(11), 1791-1795. https://doi.org/10.3923/pjn.2009.1791.1795

Ukom, A. N., Ojimelukwe, P. C., \& Alamu, E. O. (2011). All trans-cis $\beta$-carotene content of sweet potato (Ipomea batatas (L) Lam) varieties as influenced by different levels of nitrogen fertilizer application. African Journal of Food Science, 5(3), 131-137.

Umar, K. J., Hassan, L. G., Dangoggo, S. M., Inuwa, M., \& Amustapha, M. N. (2007). Nutritional content of Melochia corchorifolia (Linn.) leaves. International Journal of Biological Chemistry, 1(4), 250-255. https://doi.org/10.3923/ijbc.2007.250.255

Union for International Cancer Control/World Health Organization (UICC/WHO). (2005). Global action against cancer. Union for International Cancer Control and World Health Organization Publications Department. Geneva.

van Hal, M. (2000). Quality of sweet potato flour during processing and storage. Food Reviews International, 16(1), 1-37. https://doi.org/10.1081/FRI-100100280

van Jaarsveld, P. J., Faber, M., Tanumihardjo, S. A., Nestel, P., Lombard, C. J., \& Benadé, A. J. S. (2005). $\beta$-carotene rich orange-fleshed sweet potato improves the vitamin A status of primary school children assessed with the modified-relative-dose-response test. American Journal of Clinical Nutrition, 81(5), 1080-1087. https://doi.org/10.1093/ajcn/81.5.1080

Vimala, B., Nambisan, B., \& Hariprakash, B. (2011). Retention of carotenoids in orange-fleshed sweet potato during processing. Journal of Food Science and Technology, 48(4), 520-524. https://doi.org/10.1007/s13197-011-0323-2

Welch, R. M. (2002). Breeding strategies for biofortified staple plant foods to reduce micronutrient malnutrition globally. Journal of Nutrition, 132(3), 495S-499S. https://doi.org/10.1093/jn/132.3.495S

West, C. E., Eilander, A., \& Van-Lieshout, M. (2002). Consequences of revised estimates of carotenoid bioefficacy for dietary control of vitamin A deficiency in developing countries. Journal of Nutrition, 132(9 Suppl), 2920S-2926. https://doi.org/10.1093/jn/132.9.2920S

West, K. P. Jr. (2003). Vitamin A deficiency disorders in children and women. Food Nutrition Bulletin, 24(4), S78-S90. https://doi.org/10.1177/15648265030244S204

Wolf, J. P. (1968). Manuel d'analyses des corps gras. Azoulay (Ed.). Paris, France.

World Health Organization (WHO). (2009). Global Prevalence of Vitamin A Deficiency in Populations at Risk 1995-2005. WHO Global Database on Vitamin A Deficiency. Geneva.

Zoro, A. F., Zoué, L. T., Kra, A. K. S., Yépié, A. E., \& Niamké S. L. (2013). An overview of nutritive potential of leafy vegetables consumed in Western Côte d'Ivoire. Pakistan Journal of Nutrition, 12(10), 949-956. https://doi.org/10.3923/pjn.2013.949.956

\section{Copyrights}

Copyright for this article is retained by the author(s), with first publication rights granted to the journal.

This is an open-access article distributed under the terms and conditions of the Creative Commons Attribution license (http://creativecommons.org/licenses/by/4.0/). 